\title{
Fluvial Geomorphologic and Hydrodynamic Assessment in the Tidal Portion of the Lower Rio Grande River, US-Mexico Borderland
}

\author{
A. Ernest ${ }^{1}$, B. Bokhim ${ }^{2}$, N. B. Chang ${ }^{3 *}$, and I. J. Huang ${ }^{3}$ \\ ${ }^{1}$ Ogden College of Science and Engineering, Western Kentucky University, Bowling Green, KY 42101, USA \\ ${ }^{2}$ CBS Environmental, Inc., 6776 Southwest Freeway, Houston, TX 77074, USA \\ ${ }^{3}$ Civil and Environmental Engineering Department, University of Central Florida, Orlando, FL 32816, USA
}

\begin{abstract}
With fast population growth and economic development in the US-Mexico Borderland, water diversion and usages has reduced the flow substantially in the Low Rio Grande River (LRGR). Tidal portion of the LRGR has posed an environmental drought issue since 1993 and the channel clogged with the invasion of non-native plants also causes environmental problems. As a result of the intensity of these natural and manmade factors, the Rio Grande stopped flowing to the sea in February 2001. The flows were reduced to a point that they were unable to push out the sand deposited at the mouth. Geomorphologic evolution in association with the fluvial process of the LRGR has received wide attention. The purpose of this study is to investigate the necessary flow to maintain the river mouth open to the Gulf of Mexico using integrated approach of remote sensing and numerical analysis. It also sheds lights on possible solutions in decision-making. The analysis starts with a geomorphologic analysis using satellite remote sensing imagery and historic flow rate assessment, followed by a two-dimensional, depth averaged, finite element numerical modeling analysis to simulate the hydrodynamics of the tidal portion of the LRGR. While Landsat 7 Enhanced Thematic Mapper Plus (ETM+) satellite imagery and Digital Orthophoto Quadrangles (DOQs) were used for the geomorphologic investigation, Research Management Associates (RMA-2) software and Surface Water Modeling System (SMS 8.0) were used for minimum stream flow rate analysis. Alternative geomorphic conditions were modeled and compared to the original case, where two simulation runs were established. The first one was designed in dealing with a more refined mesh; and the second was prepared for handling an increased discharge at the inflow boundary along with the investigation of shear stress. The study concludes that the peak shear stress increased with increasing discharge towards the mouth of the river and a $1.27 \mathrm{~m}^{3} / \mathrm{s}$ discharge is necessary to maintain the opening of the river mouth.
\end{abstract}

Keywords: Environmental restoration, geomorphologic assessment, numerical model, remote sensing, sea-land interaction, watershed

\section{Introduction}

The Rio Grande (called the Rio Bravo in Mexico) is the fifth largest river in North America and its entire watershed covers an area approximately 857,600 square kilometer $\left(\mathrm{km}^{2}\right)$, with nearly half the watershed in the United States and the other half in Mexico (IBWC Website1, 2006). The river supports extensive economic development and ecosystems in three U.S. and five Mexican states. The headwaters of the Rio Grande are in the Colorado Rocky Mountains; from there the river meanders over $960 \mathrm{~km}$ in Colorado and New Mexico before reaching El Paso, Texas. From El Paso to the Gulf of Mexico, the river flows over $1,920 \mathrm{~km}$ and constitutes for a long tract of the international border line between Mexico and the United States (IBWC, 2003; Marty, 2001). In the last 40 years, the population in the communities bordering the river has doubled every 20 years. Presently, the cities along the Rio Grande (Reynosa-Matamoros on the Mexico side, and MacAllen-Brownsville on the U.S. side) are experiencing rapid urbanization with an expanding population that is expected to continue growing well into the century (TWC, 2001). In the

\footnotetext{
* Corresponding author: nchang@mail.ucf.edu
}

2006 Region M (Rio Grande) Regional Water Plan predicts the total population in the program area might increase from 1.2 million in 2000 to reach 3.8 million in 2060 (IBWC, 2006a). Also, the increased demand for municipal water is from 283.70 million $\mathrm{m}^{3} /$ year to swell to almost 772.16 million $\mathrm{m}^{3} /$ year.

From a hydrological perspective, the entire Rio Grande Basin is within an arid or semi-arid environment. For example, annual rainfall in El Paso, Texas is a scant 8 inches and the river runs dry South of El Paso during much of the year due to intensive agricultural use of water in Colorado, New Mexico, and West Texas, coupled with increasing demand for municipal water (Schmandt, 2000). Hence, the border region periodically suffers from droughts. Because the water provided by the river often is insufficient and water demands increase, these factors have caused severe water resources conflicts on both border areas. In order to reconcile the conflicts, treaties for sharing and allocating the waters of the Rio Grande/Rio Bravo between the two countries were concluded in 1906 and the International Boundary and Water Commission (IBWC) initialized an arrangement for joint water management in 1944 (IBWC Website2, 2006; Utton, 1999). A complex system of water resources management institutions has gradually emerged over time. 
Notwithstanding such a limitation of water resource, the borderlands region is home to numerous economically distressed communities (colonias), which lack adequate access to quality healthcare and clean water (TWDB, 2001). Thus, the continuously-generated problems have still threatened the ecosystem in the area. Many communities on both sides continuously released raw sewage in the river while some cities in this region just begun to build the necessary wastewater treatment facilities with primary treatment level. As the cities grew, increased levels of environmental pollution from both point and non-point sources had made water quality become a serious public health issue causing higher possibility of the incidence of water-borne disease (Jones, 2005). Thus, there are many projects working on assessments of water quality, such as IBWC Clean River Program.

Due to the impact of the North American Free Trade Agreement (NAFTA), the US-Mexico Border fast population growth and booming economic development has put additional stress on the consumption of water resources in the regional environment. Substantially, water diversion and usages has reduced the flow in the Low Rio Grande River (LRGR) and furthermore increases the risk of river flow interruption in tidal portion of the LRGR (Chávez, 1999; TCPS, 2002). Recently, clogging of the channel due to the invasion of nonnative plants also threatens ecosystems along Rio Grande River (Moore, 2002). As a result, the intensity of all these natural and manmade issues, the Rio Grande stopped flowing into the Gulf of Mexico in February 2001 (Treat, 2001; IBWC, 2003). Thereafter, an intermittent flow interruption in LRGR appears continuously. The phenomenon causes not only environmental degradation but also the loss of biodiversity (Kelly, 2002).

Therefore, based on these issues above, an overall integrated management strategy should be developed as early as possible. The study starts with a geomorphologic analysis using satellite remote sensing imagery followed by a two-dimensional, depth averaged, finite element numerical modeling analysis to simulate the hydrodynamics of the tidal portion of the LRGR. The former goal is to deal with a more broadbased illustration of the river interruption spatially, and the latter goal of the modeling development, using Research management Associates (EMA-2) and Surface Water modeling System (SMS 8.0), is to identify the minimum river inflow rate to keep river mouth open to the Gulf of Mexico.

\section{Background}

\subsection{Rio Grande Basin Environment Change}

The Rio Grande basin drains an area of approximately 335,000 square miles in Colorado, New Mexico, and Texas in the United States and Chihuahua, Durango, Coahuila, Nuevo Leon, and Tamaulipas in Mexico. It marks the international boundary from the Colorado Rockies to the Gulf of Mexico. Although the extended watershed generates diverse ecosystem and abundant cultures, the water resource also causes a longterm and complained conflict between two countries (Coronado and Kourous, 1999). In order to buffer the problem, the boundary and water treaties were made from 1848. In the
1906 and 1944 international treaties and the 1938 and 1948 interstate compacts, they have precisely defined the respective shares of the waters of the Rio Grande (IBWC Website2). With rapid urbanization and expanding population after the impact of the American Free Trade Agreement (NAFTA), the consumption of water resource in the regional environment has put more stress on Rio Grande River.

Besides, the semi-arid climate is another reason why the water provided by the river is limited and often insufficient. Precipitation and inflows periodically decline and result in a drought which occurs once every seven to ten years. The Lower Rio Grande watershed has been in a severe drought since 1993. In recent years, the invasion of weeds such as Hydrilla and Water Hyacinth is another big issue. These invasive weeds have clogged the river from a few miles upstream of the mouth. These two plants reduce the amount of water in the river through increased evapotranspiration and increased water consumption (Moore, 2002).

Due to the intensity of all these issues, the Rio Grande stopped flowing to the sea in February 2001. This happened for the first time since a historical drought occurred in the 1950 's that dried up the entire sections of the river. The flows were reduced to a point that they were unable to push out the sand deposited at the mouth (IBWC, 2003). Without periodic flushing, the tidal portion of the lower River could become a closed, hyper saline lagoon system. A study of the biological impacts to this estuary due to the closing of the river mouth suggested that the most important function of the freshwater inflows is to provide reduced salinity habitat for post-larval and juvenile marine species to complete their life cycles (Mathis, 2006). The International Boundary and Water Commission (IBWC) dredged for opening the mouth and destroyed all the water plants that were clogging the water in July 2001 (IBWC, 2003). Nonetheless, the river mouth once again closed in November 2001. But it regained its flow in October 2002 due to heavy rains in the lower valley (TNRCC, 2003). Since then, the IBWC in the United States has been seeking a permit to conduct periodic maintenance to keep the mouth open. This research provides an integrated geomorphologic and hydrodynamic analysis and modeling development to improve the water resource management in this part of the Rio Grande River.

\subsection{Study Area}

\subsubsection{Lower Rio Grande}

The Lower Rio Grande is the portion of the Rio Grande River below the International Falcon Reservoir downstream to the confluence with the Gulf of Mexico (Figure 1). This section stretches for about $450 \mathrm{~km}$ along the border between Starr, Hidalgo, and Cameron counties of Texas and the Mexico State of Tamaulipas. The Lower Rio Grande is divided into two segments: Segment 2302 Rio Grande below Falcon Reservoir from Falcon Dam in Starr County to a point $10.8 \mathrm{~km}$ downstream of the International Bridge in Cameron County, and Segment 2301 Rio Grande Tidal from a point $10.8 \mathrm{~km}$ downstream of the International Bridge in Cameron County to the 
confluence with the Gulf of Mexico (IBWC, 2006a).

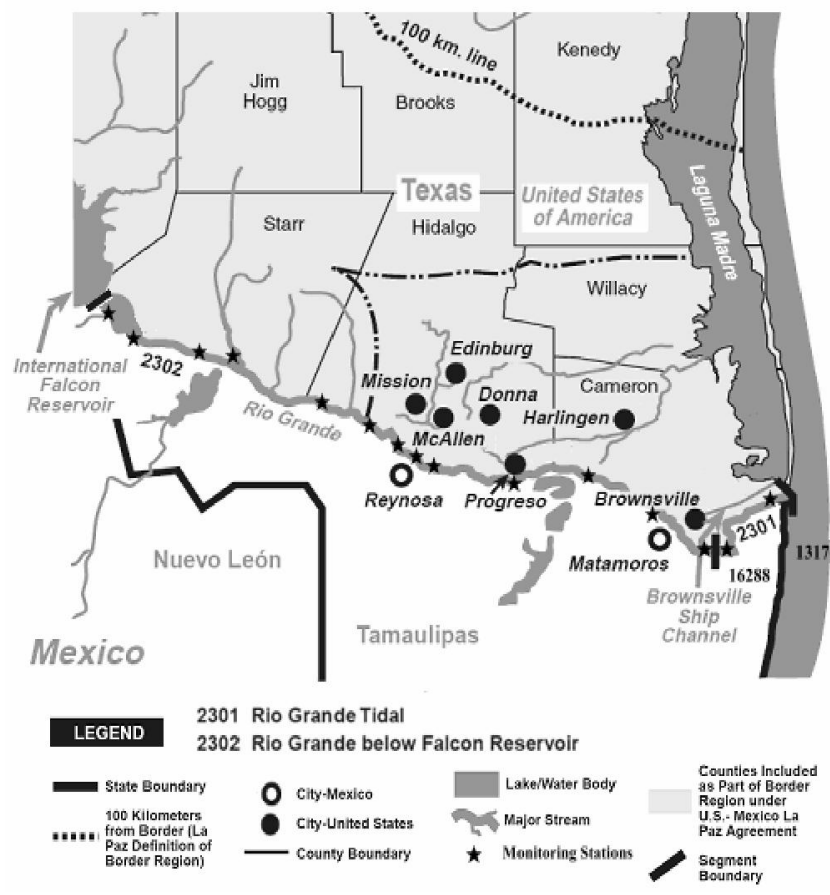

Figure 1. Location of the Study Area.

Segment 2302 is classified as a freshwater stream with a length of $371 \mathrm{~km}$ and contains 13 water quality monitoring stations. Its designated used are high aquatic life use, contact recreation, general use, fish consumption, and public water supply (IBWC, 2006a). The study area of this research, Segment 2301, is classified as a tidal stream and is designated for exceptional aquatic life use, contact recreation, general use and fish consumption. All uses are supported, except fish consumption, which has not been assessed. There are 2 monitoring stations, 13176 and 16288, in this segment. Station 13176 is located at state highway 4 near Boca Chica. Station 16288 is at Sabal Palm Sanctuary at northeast boundary off Park Road $1.6 \mathrm{~km}$ and south of FM 1419 Palm Grove (Figure 1). There are no tributaries into this segment.

\subsubsection{Water Diversions and Dam System}

Texas water resources come from two parts: surface water held in streams, rivers and reservoirs and groundwater in deep underground aquifers or shallow local aquifers. In the Lower Rio Grande Valley (LRGV), limited water quantity and impaired water quality results in significant threats to the biological, cultural and physical resources. The Rio Grande is dammed and diverted right from its headwaters. The first half of the river stops at El Paso region, located at the far west of Texas. Elephant Butte and Caballo dams store much of its water at El Paso region. After Fort Quitman it is virtually a ghost river for 250 miles until it receives new life from the Rio Conchos just above Ojinaga/Presidio. It gets another influent west of Del Rio when the Pecos and Devils rivers feed in, and an- other from the Rio San Juan just before Brownsville, where there are currently plans to build a weir to regulate the flow in tidal portion of LRGR (IBWC website1, 2006). The Rio Grande Valley is not truly a valley but a broad delta having a single distributary, the Arroyo Colorado. But this is now disconnected from the river. Water that is delivered to the lower valley is attributable to the Rio Conchos, a tributary that drains the state of Chihuahua in Mexico (Vi Risser, 1995). Throughout the basin, an extensive system of water structures captures and controls the flow of water in the subbasins to meet regional needs for flood control, power generation, and storage for domestic, agricultural, and industrial purposes (Hooper, 1997).

\subsubsection{Water Quantity}

In the Lower Rio Grande Valley, surface water flow is highly controlled by the Falcon Reservoir, the major international storage reservoir, and ground water is obtained from the Gulf Coast aquifer system of Texas and is produced in small volumes from Eocene-age strata and the Miocene-age Oakville Sandstone. With rapidly growing cities, such as Brownsville and McAllen, in the area, there are more pressures on increasing demands for freshwater. However, ground water is usually not a suitable alternative water resource within the LRGV due to high salinity and the risk of salt-water encroachment (Denny, 2002). Thus, most demanded water come form the freshwater released from the Falcon Reservoir. 2005 Regional M (Rio Grande) Water Plan shows there is more water promised through permits than there is actual water available, so one new reservoir, the Brownsville weir, is proposed to limit the freshwater inflows from the Rio Grande into the Gulf (TWDB, 2005). In addition, the 2006 Texas Clean River Program also has strategies to desalinate the brackish groundwater and seawater to supplement drinking water supplies in the lower valley (IBWC, 2006a).

In the National Stream Quality Accounting Network (NASQAN) program, the inflow and outflow of material and streamflow from the two main-stem reservoirs (Amistad International and Falcon International) were measured and the last site No.8 near Brownsville reflects the total outflow of the Rio Grande into the Gulf of Mexico. So the flows of the further downstream USGS gauge $08-4750.00$ could be referred to the flows into the mouth of the Mexico. According to the recordings (IBWC, 2006b), annual average flows have fallen to substantially lower levels from the peak of $255 \mathrm{~m}^{3} / \mathrm{s}$ in 1942 . Annual average stream flow for the entire 1934 to 2006 period is $45 \mathrm{~m}^{3} / \mathrm{s}$, but annual averages have not reached that level since 1993 because of a prolonged drought. From 1995 to 2006 (see Table 1), the average flow is only $8.5 \mathrm{~m}^{3} / \mathrm{s}$, and there were total 167 days of flow below $1 \mathrm{~m}^{3} /$ second in 1999. The extreme low flow was easy to result in intermittent river flow interruption. After 2002 see Figure 2), the increasing rainfall made the drought relieve and especially there are two month flows above the history average flow $45 \mathrm{~m}^{3} / \mathrm{s}$ in September 2004 and July 2005. Although the clogging problem does not exist at present, it is very important to efficiently manage water re- 
Table 1. The Daily Average Flow (m³/s) from 1995 to 2006 near Brownsville, USGS Gauge Site 08-4750.00

\begin{tabular}{lllllllllllll}
\hline & 1995 & 1996 & 1997 & 1998 & 1999 & 2000 & 2001 & 2002 & 2003 & 2004 & 2005 & 2006 \\
Jan. & 5.53 & 1.65 & 1.20 & 1.58 & 1.43 & 3.06 & 1.32 & 5.26 & 4.88 & 8.83 & 9.70 & 7.24 \\
Feb. & 3.45 & 1.93 & 2.00 & 4.36 & 0.69 & 0.95 & 1.72 & 7.03 & 4.59 & 8.50 & 10.5 & 7.50 \\
Mar. & 5.19 & 1.15 & 3.42 & 0.96 & 1.07 & 4.68 & 1.70 & 3.48 & 4.04 & 11.4 & 9.18 & 9.00 \\
Apr. & 4.41 & 1.90 & 3.82 & 1.91 & 1.54 & 5.15 & 3.75 & 2.59 & 2.73 & 43.5 & 10.5 & 15.6 \\
May & 6.52 & 3.19 & 1.05 & 3.76 & 1.44 & 4.65 & 2.53 & 3.38 & 2.44 & 102 & 11.3 & 15.8 \\
Jun. & 6.74 & 2.11 & 4.84 & 2.61 & 1.63 & 2.96 & 4.99 & 2.22 & 5.25 & 40.7 & 7.97 & 8.82 \\
Jul. & 2.62 & 1.76 & 2.41 & 2.77 & 2.16 & 1.14 & 3.61 & 3.31 & 5.16 & 39.8 & 55.4 & 14.3 \\
Aug. & 7.90 & 2.88 & 3.20 & 1.78 & 1.88 & 3.14 & 5.18 & 2.14 & 7.32 & 11.1 & 10.4 & 7.67 \\
Sep. & 9.12 & 3.02 & 3.16 & 6.03 & 2.29 & 2.00 & 8.45 & 6.57 & 21.7 & 68.6 & 10.8 & 27.3 \\
Oct. & 2.64 & 4.20 & 4.64 & 10.4 & 1.47 & 2.67 & 3.87 & 6.63 & 72.8 & 39.8 & 9.09 \\
Nov. & 9.48 & 2.45 & 2.45 & 2.38 & 2.08 & 1.24 & 9.56 & 9.98 & 31.7 & 12.0 & 12.6 \\
Dec. & 2.82 & 1.29 & 2.19 & 1.02 & 2.79 & 2.46 & 8.92 & 6.41 & 9.81 & 10.9 & 8.61 \\
& The Total Days of Different & Flow Range in Each Year (x) & & & & & \\
$\mathrm{x} \leqq 1$ & 61 & 105 & 72 & 89 & 167 & 104 & 32 & 0 & 0 & 0 & 0 \\
$1 \leqq \mathrm{x} \leqq 5$ & 160 & 244 & 247 & 219 & 176 & 205 & 205 & 237 & 153 & 1 & 23 \\
$5 \leqq \mathrm{x} \leqq 10$ & 97 & 25 & 37 & 47 & 22 & 39 & 89 & 101 & 128 & 111 & 104 & $104 *$ \\
$10 \leqq \mathrm{x}$ & 47 & 4 & 9 & 10 & 0 & 18 & 40 & 27 & 93 & 254 & 161 & $114 *$ \\
\hline
\end{tabular}

*The data of 2006 are only for Jan. to Sept.

sources and maintain minimum flow to keep the mouth open, especially in dry periods.

\subsubsection{Water Quality}

The water quality of the Rio Grande River is a commonly concerned issue. Since 1995 The U.S. Geological Survey (USGS) has monitored the water quality in the Rio Grande Basin as part of the National Stream Quality Accounting Network (NASQAN). The NASQAN program was designed to characterize the concentrations and transport of sediment and selected chemical constituents found in the Nation's large rivers including the Rio Grande (NASQAN Website). The USGS NAWQA (National Water-Quality Assessment) program also involves intensive water-quality studies on the examination of the effect of land use on water quality (Levings, 1998). Many studies have done about the water quality. The State of Texas contracted with the U.S. Section of the IBWC in 1998 to implement the Clean River Program (CRP, 2006) for the Rio Grande in its $2,006 \mathrm{~km}$ international boundary section (CRP, 2006).

In general, the water is of good quality in the upper sections of the basin, but the quality decreases as the water flows downstream. The decrease in downstream quality of water generally is associated with large quantities of agricultural return flow, a lack of effective wastewater treatment, and extensive year-round agriculture in the lower basin. Salinity has long been recognized as a major problem throughout the Rio Grande Basin and these large concentrations were attributed to natural saline springs, irrigation return flows and evaporation during the summer months. Also, groundwater in the LRGR is brackish resulting in the need for the building of a de- salinization plant (TWDB, 2005). Long-term accumulation of metals also could be present in the sediment because of extensive mining in New Mexico and in the Rio Conchos Basin in Mexico.

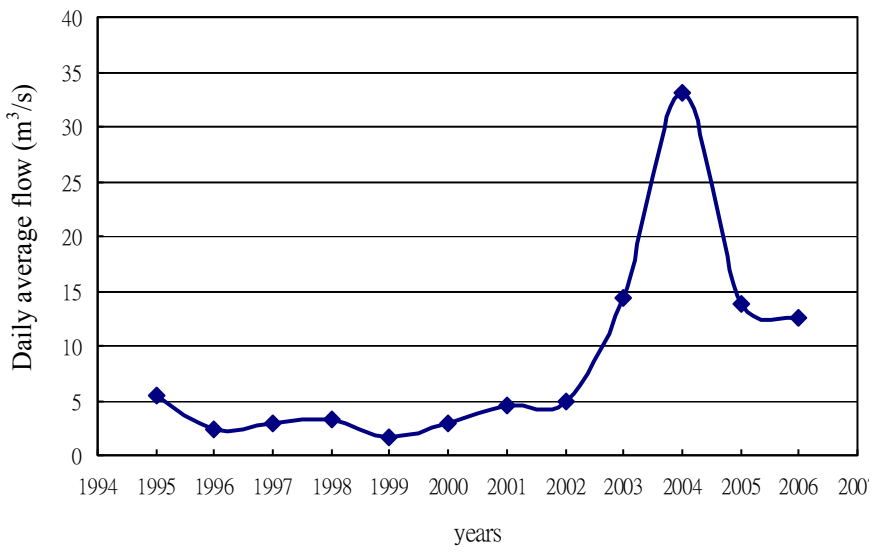

Figure 2. Daily average flows from the 1995 to 2006.

Invasive aquatic weeds, such as hydrilla and water hyacinth, were an issue in the Lower Rio Grande. These aquatic plants clogged portions of the river preventing boat traffic, hinder water flow and increase water loss through consumption and evapotranspiration. Mechanical removal, biological control and heavy rains made the problem reduce significantly in 2003. Although the problem was solved temporarily, continued maintenance and normal river flows should keep the interruption from occurring again. According to the Texas Clean River Program (IBWC, 2006a), the most concern in the Lo- 


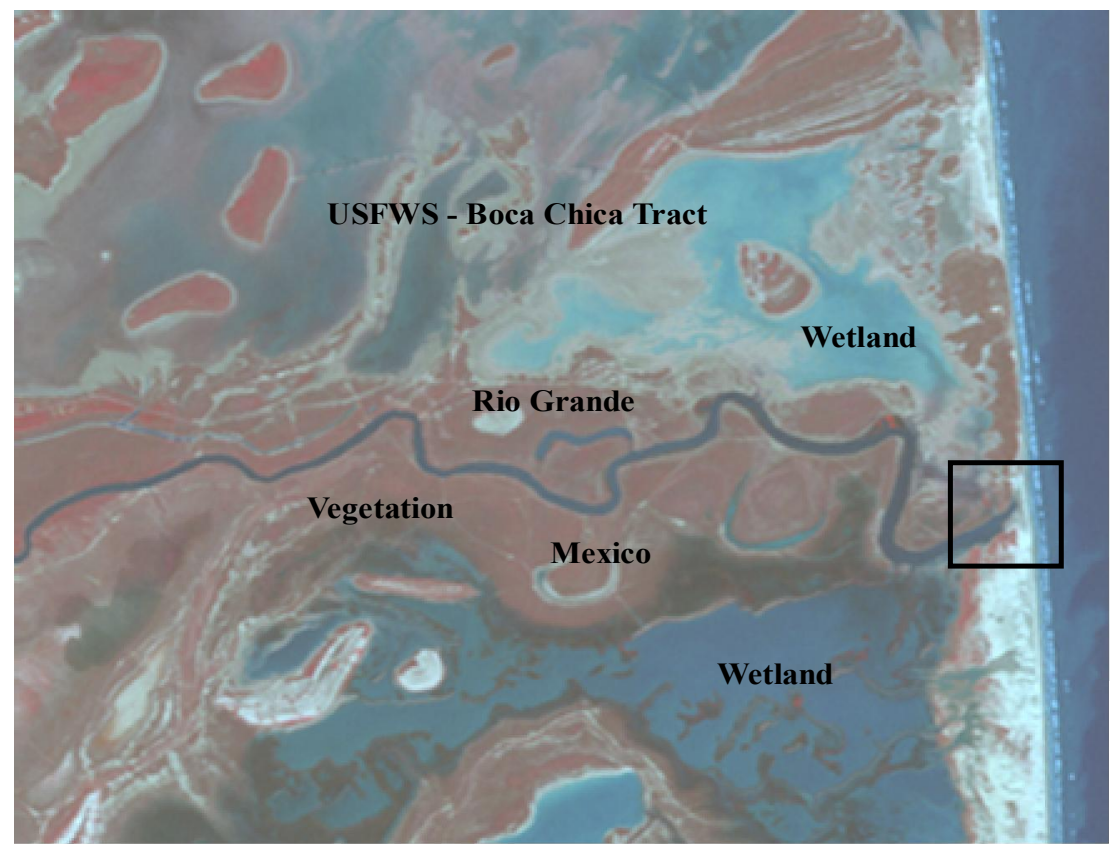

Figure 3. Landsat 7 remote sensing imagery in Lower Rio Grande River.

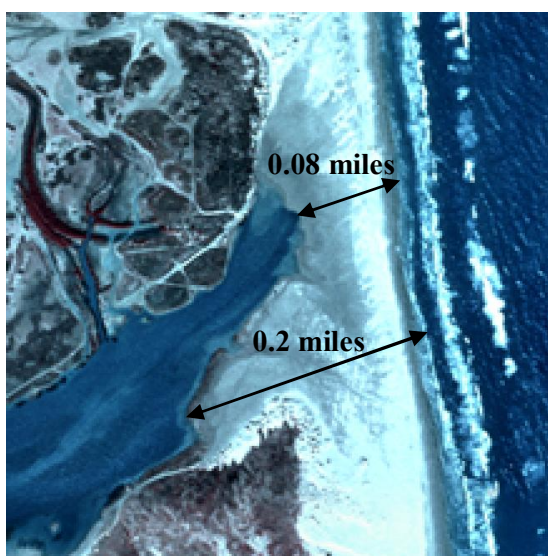

(a)

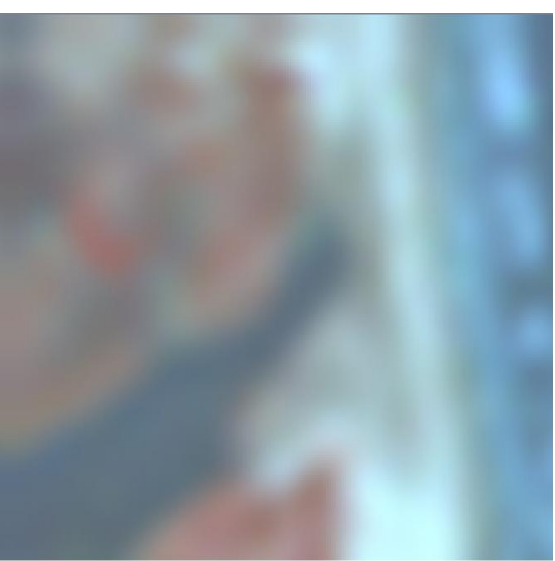

(b)

Figure 4. Comparison between 1-meter Color DOQQ imagery in (a) and 30-meter Landsat 7 remote sensing imagery in (b) at the mouth of the Lower Rio Grande River.

wer Rio Grande is excessive algal growth as indicated by periodic high chlorophyll-a levels (Jago, 1999). One of the greatest threats to water quality is the lack of sufficient water and wastewater infrastructure to keep pace with border growth.

\subsubsection{New Environmental Issues in the Lower Grande River}

Due to the change of water demand and usage in Lower Rio Grande, alternative water supply management strategies need to be re-evaluated. By far 85 percent of the existing water rights on the LRG are authorized for irrigation use and annual average is more than 2,220 million $\mathrm{m}^{3}$. Historical use quantities indicate that there are more authorized diversions for irrigation than are actually needed (TEP Website, 2006). Based on TWDB 2005 Region M Water plan, demands for irrigation will decrease from about $1,435.78$ million to $1,211.27$ million $\mathrm{m}^{3} /$ year. On the contrary, the total municipal water demand will increase form about 345.37 million $\mathrm{m}^{3} /$ year in 2010 to about 772.16 million $\mathrm{m}^{3} /$ year in 2060 . Thus, modify the allocation of water rights can make water more effectively use and enhance the available future supply of water from Amistad and Falcon reservoirs.

Because of the interruption of the Lower Rio Grande River near the Gulf of Mexico, the tidal portion of the lower River could become a closed, hyper saline lagoon system. In 
order to protect form the situation, a weir near Brownsville is projected to control the freshwater inflows into the Gulf. However, the potential impact of ecological environment in the LRGR really needs to be analyzed completely, such as the necessary amount of freshwater inflows for restoring the habitats and keeping the mouth open. Also, efficient conservation and drought management are very important to save water resource.

\section{Geomorphologic Application}

\subsection{Satellite Remote Sensing Imagery}

Satellite based sensors, like Landsat Thematic Mapper, have also been used successfully with GIS to estimate the impact of vegetation on floodplain of the Amazon River, (Mertes, 1995), and quantify the erosion patterns in the Brahmaputra Jamuna River (Khan, 2003). Landsat 7 is the latest satellite in NASA's Earth Sciences Enterprise, a long-term program to characterize, monitor, explore, and observe natural and manmade environmental changes on Earth. Landsat 7 was launched in 1999 and carried the Enhanced Thematic Mapper Plus (ETM+) Sensor that has 30 meters for the visible and near infrared spatial resolution (bands 1 to 5 and 7). Resolution for the panchromatic (band 8) is 15 meters and the thermal infrared (band 6) is 60 meters. It provides 16-day repetitive Earth coverage, high quality visible, infrared and substantially cloud free images (USGS Website1).

For smaller river or special purposes, airborne remote sensing (like aerial photography) is a more suitable approach (Bryant, 1999). However, the Digital Orthophoto Quadrangles (DOQ) is a computer-generated uniform scale image of an aerial photography that removes the disadvantages of image displacements caused by the tilting of the camera and terrain relief. Because of its map-like qualities, a DOQ can be used for any number of professional cartographic and land-management purposes. The standard DOQ's produced by the U.S. Geological survey (USGS) are grayscale or color-infrared (CIR) images with a 1-meter ground resolution. They cover an area measuring 3.75-minutes longitude by 3.75-minutes latitude, approximately $8 \mathrm{~km}$ on each side (USGS Website2). Figure 3 describes the geographical environment of the mouth area.

A unique comparison of remote sensing imageries can be made for the area nearby the mouth of the LRGV. In Figure 4, the Digital Orthophoto Quarter Quadrangle (DOQQ) imagery (in 4a) collected on 8 February 2002 can be compared against the Landsat 7 remote sensing imagery (in 4b), collected on 6 January 2002 from the Seamless Data Distribution System of USGS. It turns out to be that the Lower Rio Grande River can be seen clearly between the United States and Mexico's border line and vegetation (the red area) covers along the river and wetlands (the blue area) cover the other area in $4 \mathrm{a}$. It shows the sandbar blocked the river flowing into the Gulf of Mexico. However, Landsat 7 may not be seen clearly in $4 \mathrm{~b}$ to measure the distance of the sandbar block because it has only 30-meter resolution. The shortest block distance is $0.128 \mathrm{~km}$ and the longest one is $0.32 \mathrm{~km}$ near the mouth of the river as moni- tored on 6 January 2002.

\subsection{Hydrodynamic Research}

The estuary's functionality is also threatened by the water development projects in the lower basin (McAllen to Brownsville) that include water diversion and waste water treatment. Water diversion projects can severe the freshwater quantity problems and wastewater treatment projects can increase water quality problems through discharges of polluted water into, or upstream of, the tidal portion of the River. Consequently, lower flows, coupled with increased nutrient and/or contaminant loads, will create eutrophic or noxious conditions harmful to a healthy estuary (e.g. excessive nutrient loads could lead to harmful algalblooms or excessive growths of noxious plants such as hydrilla or water hyacinth (Moore, 2002). On the other hand, the return flows of water diverted from the Rio Grande/Rio Bravo currently pass down the Arroyo Colorado, which empties into the Laguna Madre. Laguna Madre is the estuary north of the River's estuary. If some of this diverted water were re-routed from the Arroyo Colorado via pipeline to the tidal portion of the River, it might be sufficient to satisfy the minimal target freshwater inflow requirements of the estuary (Moore, 2002). Based on the discussion above, there are two critical researches needs for the determination of the minimum river inflows required (1) to maintain a healthy, ecologically-sound environment capable of supporting characteristic, economically-important estuarine fisheries, and (2) to keep the river mouth physically open to the Gulf of Mexico. The following modeling analysis was designed to answer the second question solely.

\subsubsection{Modeling Formulation}

A part of the Gulf of Mexico was also included in the mesh because tidal water interacts with the flow of the river, especially near the mouth. Boundary conditions were designnated both by inflow (designated as constant at upstream boundary in the study domain) and by the water surface elevation (dynamic head) at a radial distance of one mile from the mouth. The input data such as the flow and the tidal elevations were obtained from the on-line data from various agencies and research institutes. The model output at each time step specified is comprised of water surface elevation and horizontal velocity. Animations of the water velocity showing the water flow inside the mesh and the flow trace were created through the post-processing attribute of SMS. A sensitivity analysis was also performed to show the response of various values of the input parameters. However due to the unavailability of additional data set, the simulated values could not be verified with data from a different source.

The governing equations and the solutions in RMA-2 can be described as the following:

$$
\begin{aligned}
& h \frac{\partial u}{\partial t} \cdot h u \frac{\partial u}{\partial x}+h v \frac{\partial u}{\partial y}-\frac{h}{\rho}\left(\varepsilon_{x x} \frac{\partial^{2} u}{\partial x^{2}}+\varepsilon_{x y} \frac{\partial^{2} u}{\partial y^{2}}\right)+g h\left(\frac{\partial a}{\partial x}+\frac{\partial h}{\partial y}\right) \\
& +\frac{g u n^{2}}{1.486 h^{1 / 6}}\left(u^{2}+v^{2}\right)^{1 / 2}-\zeta V_{a}^{2} \cos \psi-2 h \omega u \sin \phi=0
\end{aligned}
$$




$$
\begin{aligned}
& h \frac{\partial v}{\partial t} \cdot h u \frac{\partial v}{\partial x}+h v \frac{\partial v}{\partial y}-\frac{h}{\rho}\left(\varepsilon_{x x} \frac{\partial^{2} v}{\partial x^{2}}+\varepsilon_{x y} \frac{\partial^{2} v}{\partial y^{2}}\right)+g h\left(\frac{\partial a}{\partial x}+\frac{\partial h}{\partial y}\right) \\
& +\frac{g v n^{2}}{1.486 h^{1 / 6}}\left(u^{2}+v^{2}\right)^{1 / 2}-\zeta V_{a}^{2} \sin \psi-2 h \omega u \sin \phi=0 \\
& \frac{\partial h}{\partial t}+h\left(\frac{\partial u}{\partial x}+\frac{\partial v}{\partial y}\right)+u \frac{\partial h}{\partial x}+v \frac{\partial h}{\partial y}=0
\end{aligned}
$$

$$
\begin{aligned}
\text { where } & \\
h \quad= & \text { Depth } \\
u, v \quad= & \text { Velocities in the Cartesian directions } \\
x, y, t= & \text { Cartesian coordinates and time } \\
\rho \quad= & \text { Density of the fluid, } \mathrm{lb} / \mathrm{ft}^{3} \\
\varepsilon \quad= & \text { Eddy viscosity coefficient, lb-sec/ } \mathrm{ft}^{2} \\
& \text { for } x x=\text { normal direction on } x \text { axis surface } \\
& \text { for } y y=\text { normal direction on } y \text { axis surface } \\
& \text { for } x y \text { and } y x=\text { shear direction on each surface } \\
g \quad= & \text { Acceleration due to gravity, ft/sec }{ }^{2} \\
a \quad= & \text { Elevation of bottom, } \mathrm{ft} \\
n \quad= & \text { Manning's roughness } \mathrm{n}-\mathrm{value} \\
1.486= & \text { Conversion from SI to non-SI units } \\
\zeta \quad= & \text { Empirical wind shear coefficient } \\
V a \quad= & \text { Wind speed, } \mathrm{ft} / \mathrm{sec} \\
\psi \quad= & \text { Wind direction } \\
\omega \quad= & \text { Rate of earth's angular rotation } \\
\phi \quad= & \text { Local latitude }
\end{aligned}
$$

Equations 1 to 3 are solved by the finite element method using the Galerkin method of weighted residuals. The solution is fully implicit and the set of simultaneous equations is solved by Newton-Raphson nonlinear iteration (Donnell, 2000). Generally, less than eight iterations are required to obtain a valid solution, depending upon the difference between the initial conditions and the final solutions.

\subsubsection{Boundary and Flow Conditions}

A flow boundary condition is specified as either total flow or velocity. They are normally provided at inflow locations, and are used to specify the amount and direction of the fluid entering the mesh. Each sidewall of the network is automatically assigned a parallel flow boundary condition (i.e. slip flow), which allows the program to calculate the velocity adjacent and parallel to the sidewall as well as the flow depth there.

In the process of model application, the lower portion of segment 2301 (downstream of the International Bridge in Cameron County to the confluence with the Gulf of Mexico) was chosen. There is no USGS station at the Tidal portion (segment 2301) of the Lower Rio Grande River. The nearest USGS station, with the station number 08-4750.00, is located near Brownsville, Texas and Matamoros, Tamaulipas (IBWC, 2006b). Real-time stream flow data are provided since January 1,1934 , so the flow data was taken from this station. It was assumed that the flow at the inflow boundary condition is the same as that of the Brownsville station. This station is about 2 miles upstream from the inflow boundary point. There is a TNRCC station (station no. 13176) on segment 2301. However, this station does not have the flow data. It measures only water quality parameters. Three days of lowest flows in 2002 was averaged and used as the boundary condition. The lowest inflow discharge averages $42.73 \mathrm{ft}^{3} / \mathrm{sec}$ in 2002 . The average water discharge was $45.55 \mathrm{ft}^{3} / \mathrm{sec}$ for the three-day time period considered for the simulation. The flow discharge is specified in the boundary conditions file.

\subsubsection{Verification and Sensitivity Analysis}

A final model was created with the adjusted parameters such that the result is fairly similar to the observed values. The unavailability of more data sets for the study area limited the possibilities of extensive verification of the model. Same data were used for both calibration as well as verification. So the model cannot be considered as a fully verified model. RMA2 provides a number of parameters, which can be adjusted to yield the best possible simulated values compared to the measured ones. A sensitivity analysis was performed to evaluate the effects of variations in the different parameters on the model results. The set of four parameters shown in Table 2 were adjusted to show the effect of each parameter. Sensitivity analysis pinpoints the most important parameters that affect the model.

Table 2. RMA-2 Model Parameters Varied for the Sensitivity Analysis

\begin{tabular}{lccc}
\hline Parameter & Low Value & Calibrated Value & High Value \\
\hline Manning's $n$ & 0.036 & 0.04 & 0.044 \\
Peclet Number & 15 & 18 & 22 \\
Time Step (hours) & 0.4 & 0.5 & 1.0 \\
Wind Speed (mph) & 9.5 & 9.8 & 13.9 \\
\hline
\end{tabular}

\subsubsection{Animation}

Model creation, verification and sensitivity analysis was finally followed by an animation of the flow of water using the post-processing attribute of SMS 8.0 (SMS Reference Manual). SMS contains the capability for creating contour plots of scalar data on a finite-element mesh. Three different types of contours are available, including normal linear contours, color fill between contours, and cubic spline contours. The user controls the number of contours, the contouring interval, minimum and maximum contour values, labeling options, bolding contours and the color scale. SMS can also produce vector plots from vector data on a finite element mesh. The user controls the arrowhead style and size, vector length, vector placement and density and color. Flow animation for the model was generated using the dynamic data set to illustrate how water flows as a function of time inside the mesh.

\subsubsection{Refined Mesh}

The mesh was refined from a total number of 459 elements and 1,056 nodes to 1,833 elements and 3,944 nodes. To 


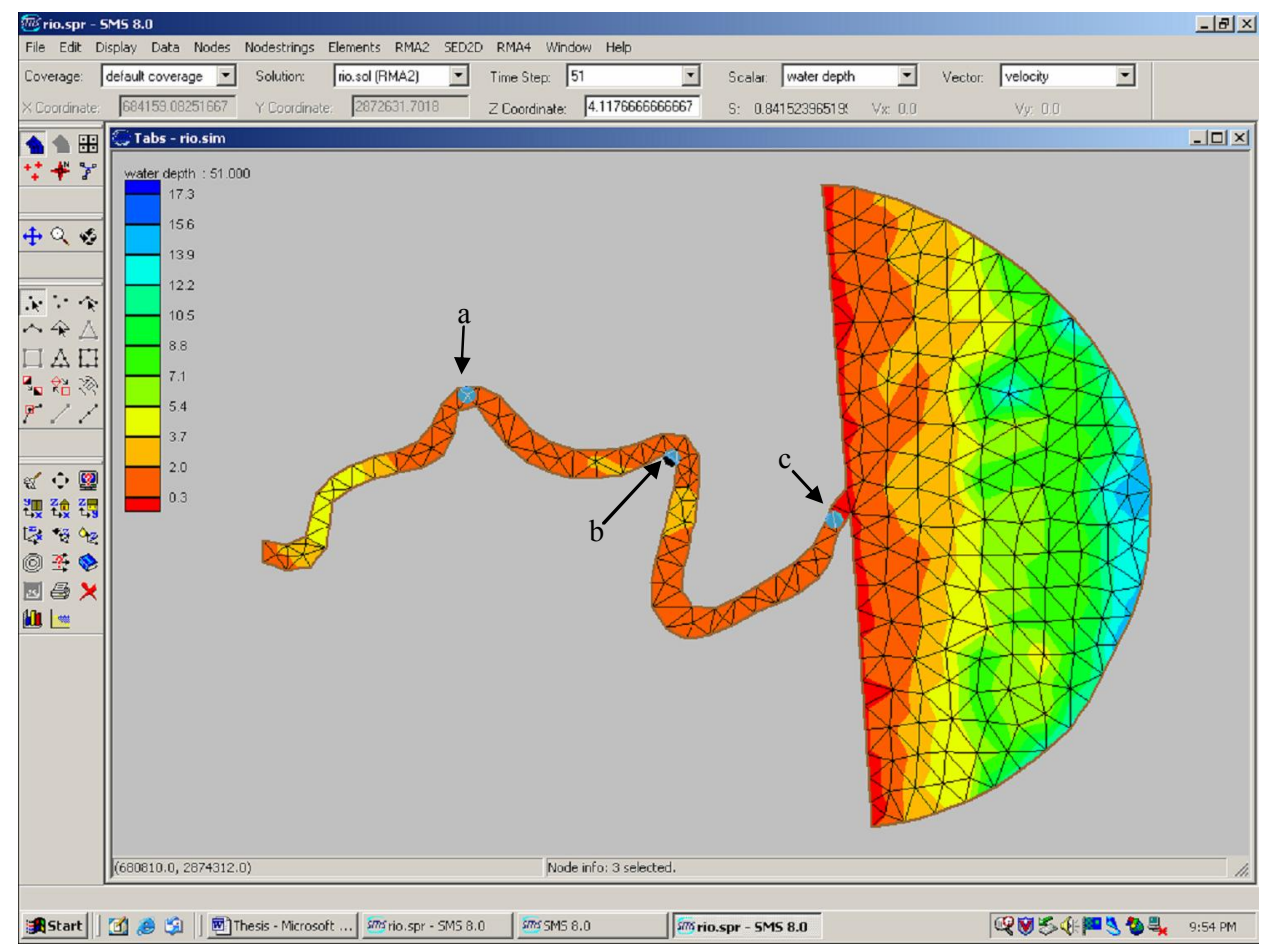

Figure 5. Three places where shear stress was chosen for comparison.

do this, refine tool from the Mesh module was used. Input values were same as the calibrated values of the original mesh. Water surface elevations and the velocity magnitude from the refined mesh were compared to the original mesh.

\subsubsection{Shear Stress at different discharges}

One of the main objectives of this study is also to calculate the minimum discharge needed at the Brownsville station to calculate the minimum flow required to open the mouth physically to the Gulf of Mexico. The minimum velocity required at the mouth is 0.3 to $0.36 \mathrm{~m} / \mathrm{s}$ for the river to flow to the gulf naturally (Jepsen et al., 2001). The discharge at the inflow was increased until the average velocity of the 26 nodes at the mouth was more than $0.3 \mathrm{~m} / \mathrm{s}$ at the lowest tide level. For the river to flow naturally to the gulf, the shear stress at the river should be greater than the shear stress of the beach at the gulf. In region of uniform Manning's coefficient $n$, creating plots of shear stress is possible within SMS. Manning's formula is given by:

$V=\frac{1.486}{n} R^{2 / 3} S^{1 / 2}$

where $V$ is the depth-averaged velocity, $n$ is Manning's coefficient, $R$ is the hydraulic radius (assumed to be the local water depth), and $S$ is the river slope.

Shear Stress is given by:

$\tau=\rho g R S$ where $\tau$ is the shear stress at the bed, $\rho$ is the density of water, $g$ is gravity, $R$ is the hydraulic radius, and $S$ is the river slope. Combining Equations (4) and (5) and eliminating the slope of the river slope yields:

$$
\tau=\frac{V^{2} \rho g}{\left(\frac{1.486}{n}\right)^{2} R^{1 / 3}}
$$

Using the data calculator attribute of the Mesh Module, scalar data sets of the Shear Stress can be constructed using Equation (6).

Shear stress was calculated at different discharges and at different places in the river and compared to the results obtained by the Sandia National Laboratories (Jepsen et al., 2001). Three places $a, b$ and $c$ were chosen and the shear stress calculated at different discharge of 45.55, 100 and 150 $\mathrm{ft}^{3} / \mathrm{s}$ (see Figure 5).

\section{Results and Discussion}

This study showed that the simulated and the measured values of the water elevation are within the same bulk number. The simulated water surface elevation at the discharge was around $1.77 \mathrm{~m}$ at all time steps, where the measured gage height at Brownsville station is about $7 \mathrm{ft}$. In the upstream river portion, all the output values such as the velocity, depth and water surface elevation did not change much with time. 
The case was just the opposite in case of the Gulf. Since velocity at the mouth changed drastically during the 72 hours of simulation period, 26 nodes were selected at or near the mouth and the average velocity was plotted against time. In other places, the velocity also did not change much. As expected the average velocity of the 26 nodes at the mouth of the river was high during the low tides and low during the high tides. During the high tides, the water from the gulf flowing inward would counter the flow coming out from the mouth of the river, thereby reducing the flow. While during the low tides, the flow from the mouth of the river would be in the same direction as the flow of the tides. The highest average velocity of the 26 selected nodes, observed at the mouth was $0.128 \mathrm{~m}$ at time step of 27.0 hours when the tide was lowest at $-0.093 \mathrm{~m}$.

The simulated values of the water surface elevations and the velocities from the refined mesh were quite close to the results from the original mesh. However, with the refined mesh there was a slight increase in velocity and even the water elevation values were slightly closer to the observed values (see Figures 6 and 7). The discharge at the inflow was kept on increasing until the velocity at the mouth became $0.3 \mathrm{~m} / \mathrm{s}$ or greater than $0.3 \mathrm{~m} / \mathrm{s}$. The intended velocity of greater than 1 fps was obtained at the mouth when the discharge was set to $4.05 \mathrm{~m}^{3} / \mathrm{s}\left(150 \mathrm{ft}^{3} / \mathrm{s}\right)$. Highest value of velocity was $0.312 \mathrm{~m} / \mathrm{s}$ at $51 \mathrm{st}$ hour when the water elevation was the least at -0.114 $\mathrm{m}$ (see Figures 8 and 9).

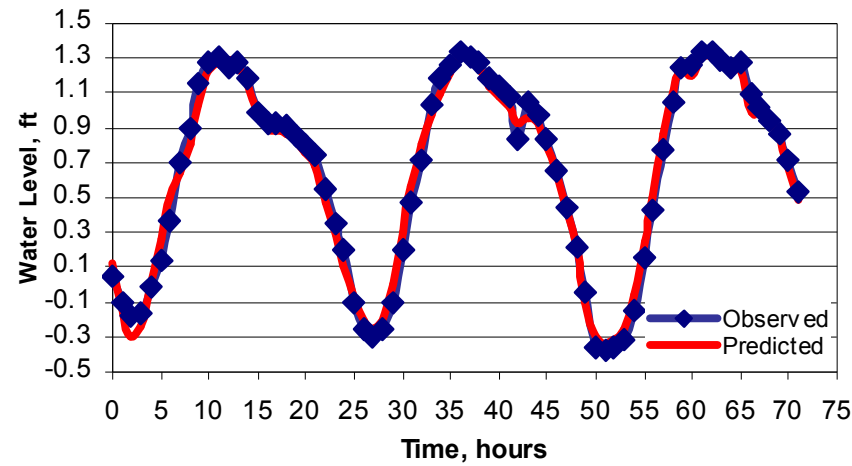

Figure 6. Variation of predicted and observed water level.

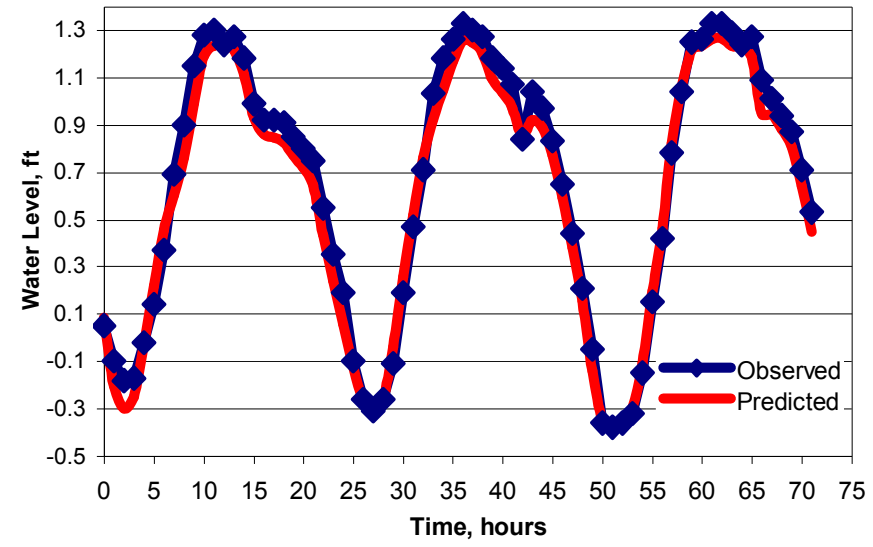

Figure 7. Variation of predicted and observed water level due to the refined mesh.
During all the time steps, the shear stress at the river was greater than the shear stress at the gulf. The study conducted by the Sandia National Laboratories at the river (at least $75 \mathrm{~m}$ into the channel) showed that the materials were very similar in erosion properties and particle size. These sediments were homogeneous mixtures of sand with critical shear stress for erosion between 0.25 and $0.35 \mathrm{~Pa}$ (Figure 10). In addition, these sediments transported completely as bed load at shear stresses of $0.5 \mathrm{~Pa}$ or lower. Peak shear stresses were calculated at three different places with various discharges using the data calculator option in SMS. The closest simulated values were obtained at place $\mathrm{c}$ (i.e. the mouth of the river) at a discharge of $1.229 \mathrm{~m} \mathrm{~m}^{3} / \mathrm{s}\left(45.5 \mathrm{ft}^{3} / \mathrm{s}\right)$. The shear stress increased towards the mouth with increasing discharge. More snapshots of model animation can be found in the Appendix.

\section{Conclusions}

This research investigates the flow background of LRGR and flow interruption issues in recent ten years to provide scientific assessment for improving the water resource management policy. The simulated water elevation showed a bulk agreement with the measured values. In the upstream river portion, the output values such as the velocity, depth and water surface elevation did not change with time. The change was most prominent at the mouth of the river. As expected, the velocity at the mouth was high during low tides and low during high tides. Velocity increased with increasing wind speed and Peclet number but decreased with increasing friction factor. The depth also changed with changing water surface elevation. A more refined mesh gave slightly better results. An intended velocity of greater than $0.3 \mathrm{~m} / \mathrm{s}$ was obtained at the mouth when the discharge was set to $4.05 \mathrm{~m}^{3} / \mathrm{s}$. Highest value of velocity was $0.32 \mathrm{~m} / \mathrm{s}$ at $51^{\text {st }}$ hour when the water elevation was at its lowest. The shear stress increased towards the mouth of the river with increasing discharge. Biodiversity encourages increase in the discharge of water to maintain a healthy estuary. This suggested that water should not be diverted or rerouted from the river. But in case of morphological point of view, increasing the stream flow rate is not encouraged as sediments, which are eroded at these two bends nearby the mouth of the river, are highly likely transported and deposited at the mouth. So there should be a threshold of the stream flow rate. Dredging for the removal of sand layer to open the mouth is also advised though it is very expensive. The two-dimensional flow simulations results can be used to perform the contaminant migration and sediment transport analysis. For example, this is very important in assessing the susceptibility of public water intakes to contaminants. The study finally concludes that the peak shear stress increased with increasing discharge towards the mouth of the river and a $1.27 \mathrm{~m}^{3} / \mathrm{s}$ discharge is necessary to maintain the opening of the river mouth. Finally, from an engineering perspective, building of grouted riverbanks to prevent erosion at the bends is highly recommended.

However, one of the deficiencies in the modeling study is lacking field data. The model was calibrated and validated with the same set of real world data obtained from National 
Oceanic and Atmospheric Administration (NOAA). A differrent set of data would be needed for verification of the model. The model should be verified in case of velocity as well. The hydrodynamic model applied here cannot be taken as a completely verified model because the simulated values were not compared with a different data set. The same data set was used to calibrate and verify the model. Additional data collection, model calibration analysis, and grid refinements are needed to assess and enhance two-dimensional flow simulation capabilities describing the horizontal flow distributions.

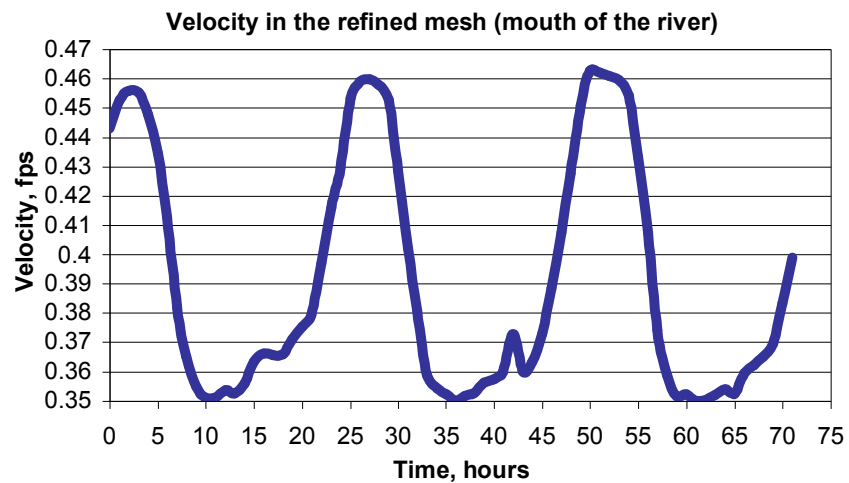

Figure 8. Differences in water velocity due to the refined mesh.

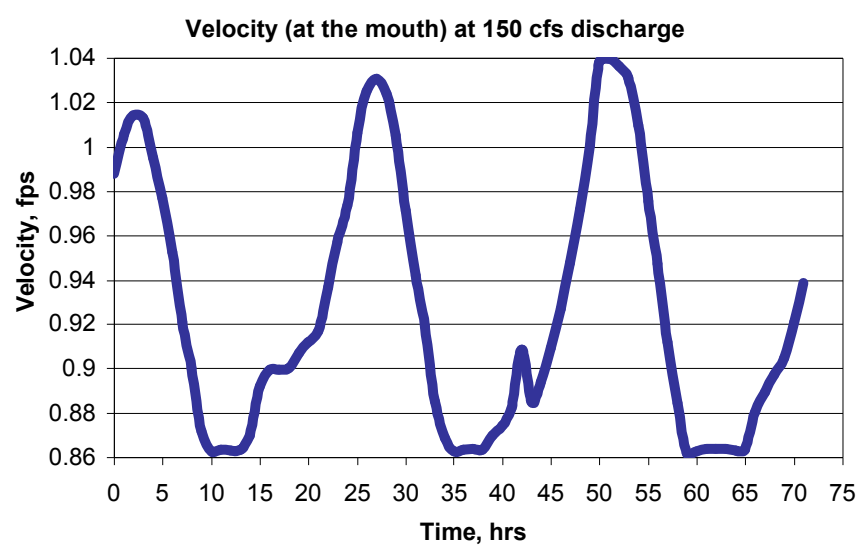

Figure 9. Differences in water velocity due to the increased discharge.

Some future work can be listed as follows:

- Salt-water intrusion and salinity changes should be studied with a three-dimensional model such as RMA-10. Salt concentration in the water is very important to maintaining its flora and fauna.

- It is impossible to model natural systems without involving uncertainty and even the most sophisticated models cannot predict the hydrodynamics with a sound accuracy. Therefore, it is necessary to evaluate the uncertainties involved in any modeling practice in order to improve the reliability of the hydrodynamic models in their application to specific water body systems.
- Accuracy of Digital Elevation Model ( DEM) is always in question. For example, DEMs do not accurately represent depressions or flat areas, which could occur due to insufficient data or interpolation errors during DEM production (Garbrecht, 1995). So to achieve more accurate representation of surface hydrology, flow algorithm like nearest-neighbor steepest descent (D8 algorithm) or Fractional (F8 algorithm) can be used which will partition a study watershed into subwatershed areas. Also, survey-quality measurements should be used if available.

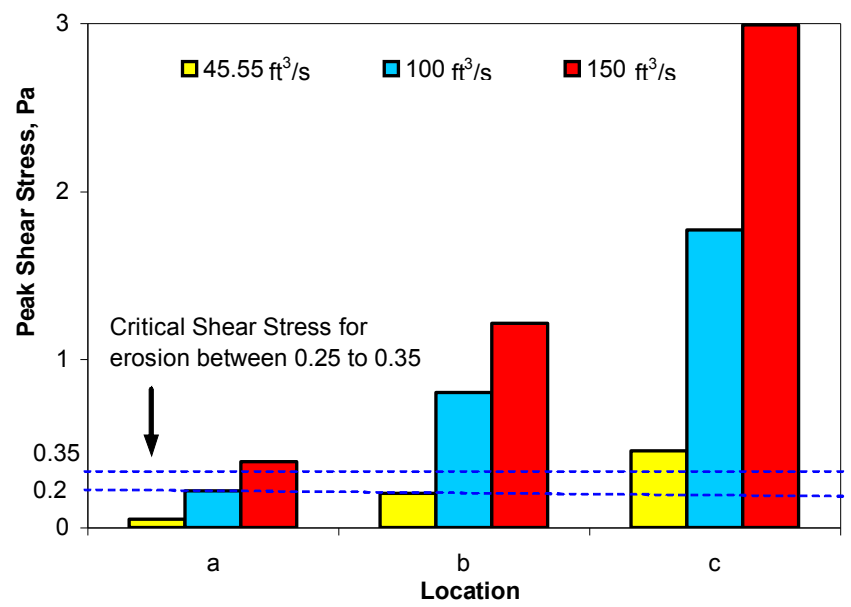

Figure 10. Shear stress at different discharges and locations.

\section{References}

Bryant, R.G. and Gilvear, D.J. (1999). Quantifying geomorphic and riparian land cover changes either side of a large flood event using airborne remote sensing: River tay, Scotland. Geomorphology, 29, 307-321.

Chávez, O.E. (1999). The 1994-1999 drought, What did we learn from it? The mexican perspective. Nat. Resour. J., 39(1), 35-36.

Coronado, I. and Kourous, G. (1999). Water conflict in the borderlands. Borderlines, 57, 7(6).

CRP website (2006). The Texas clean river program. http://www. ibwc.state.gov/CRP/monstats.htm.

Denny, B., Diana, P., George, O., Dennis, W., Mark, F. and Larry, D. (2002). Water-Resources Issues in the Lower Rio Grande ValleyBelow Falcon Reservoir to the Gulf of Mexico Subarea, US Department of the Interior Field Coordinating Committee Fact Sheet 4.

Donnell, B.P., Letter, J.V., McAnally, W.H. and Thomas, W.A. (2000). Users Guide to RMA2 WES Version 4.5, US Army Corps of Engineers Waterway Experiment Station, 264.

Garbrecht, J. and Starks, P. (1995). Note on the Use of USGS Level 1 7.5-Minute Dem Coverages for Landscape Drainage Analyses. Photogram. Eng. Remote Sens., 61(5), 519-522.

Hooper, R.P., Goolsby, D.A., Rickert, D.A. and McKenzie, S.W. (1997). NASQAN-A Program to Monitor the Water Quality of the Nation's Large Rivers, US Geological Survey.

IBWC (2003). 2003 Regional Assessment of Water Quality in the Rio Grande Basin by Texas Clean Rivers Program and United States Section, International Boundary and Water Commission. 
IBWC (2006a). 2006 Basin Highlights Report for the Rio Grande Basin by Texas Clean Rivers Program and United States Section, International Boundary and Water Commission.

IBWC (2006b). Rio grande water flows. http://www.ibwc.stage.gov/ $\mathrm{wad} /$ histflo1.htm.

IBWC Website1 (2006). Study area in clean river program. http://ww w.ibwc.state.gov/CRP/Stdyarea.htm\#.

IBWC Website2 (2006). The boundary and water treaties. http://www. ibwc.state.gov/html/treaties.html.

Jones, E.C. (2005). A Survey of Databases Covering Specific WaterBorne Diseases and Water Contaminants in the US-Mexico Border Region, The Pan American Health Organization, Durham, NC.

Jepsen, R., Langford, R., Neu, R., Chapin, D.M. and Buhalts, R. (2001). Sediment Erosion and Transport at the Rio Grande Mouth, Report for the National Border Technology Program and International Boundary and Water Commission, Sandia National Laboratories, Albuquerque, NM.

Jago, R.A., Cutler, M.E.J. and Curran, P.J. (1999). Estimating canopy chlorophyll concentration from field and airborne spectra. Remote Sens. Environ., 68, 206-216.

Kelly, M. (2002). Water management in the binational Texas/Mexico Rio Grande/Rio Bravo basin. Yale Foresty Environ. Stud. Bull., 115-148.

Khan, N.I. and Islam, A. (2003). Quantification of erosion patterns in the Brahmaputra-jamuna river using geographical information system and remote sensing techniques. Hydrol. Process., 17, 959-966.

Levings, G.W., Healy, D.F., Richey, S.F. and Carter, L.F. (1998). Water Quality in the Rio Grande Valley, Colorado, New Mexico, and Texas, 1992-95, US Geological Survey Circular 1162.

Marty, F. (2001). Managing International Rivers: Problems, Politics and Institutions, Peter Lang, Bern, The Rio Grande Rectification Project, pp. 126-159.

Mertes, L.A.K., Danial, D.L., Melack, J.M., Nelson, B., Martinelli, L.A. and Forsberg, B.R. (1995). Spatial patterns of hydrology, geomorphology and vegetation on the floodplain of the Amazon River in Brazil from a remote sensing perspective. Geomorphology, 13, 215-232.

Mathis, M.L. (2006). The Economic Value of Water and Ecosystem Preservation Part 2: Freshwater Inflows from the Rio Grande,

\section{Appendix}

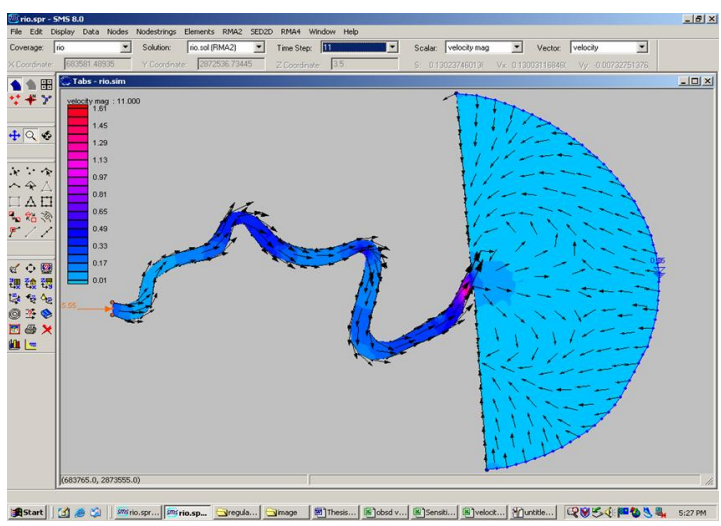

Figure A1. Snap shot of the water flow during the first high tide at 11 th hour.
The Texas Coastal Management Program.

Moore, J.G., Rast, W. and Pulich, W.M. (2002). Proposal for and Integrated Management Plan for the Rio Grande/Rio Bravo, First International Symposium on Transboundary Waters Management, Monterrey, Nuevo Leon, Mexico.

NASQAN Website. National stream ouality accounting network project. http://water.usgs.gov/nasqan/.

Schmandt, J., Aguilar-Barajas, I., Mathis, M., Armstrong, N., ChapaAleman, L., Contreras-Balderas, S.R., Hazelton, E. J., NavarChaidez, J., Vogel-Martinez, E. and Ward, G. (2000). Water and Sustainable Development in the Binational Lower Rio Grande/Rio Bravo Basin, EPA/NSF Water and Watersheds Grant Program.

SMS Reference Manual. Surface-Water Modeling System (SMS), Brigham Young University, Version 8.0.

Treat, J. (2001). Mexico and US cut Rio Grande deal, but tensions run high as border water runs low. Borderlines, 78, 9(5).

TCPS (2002). The dispute over shared waters of the Rio Grande/Rio Bravo, Texas Centre for Policy Studies (TCPS): 17.

TEP Website (2006). Water quantity and water quality, Texas Environmental Profiles. http://www.texasep.org/index.html.

TNRCC (2003). Watermaster programs, Texas Natural Resource Conservation Commission. http://www.tnrcc.state.tx.us/enforce ment/fod/wmaster/wmaster1.html.

TWDB (2001). 2001 Regional water plan (Regional M-Rio Grande), Texas Water Development Board.

TWDB (2005). 2005 Regional water plan (Regional M-Rio Grande), Texas Water Development Board.

TWC (2001). Texas rapid access to career and economic resources (TRACER), Texas Workforce Commission. http://www.twc.sta te.tx.us.

USGS Website1 (2006). Enhanced thematic mapper plus (ETM+). http: //edc.usgs.gov/products/satellite/landsat 7.html.

USGS Website2 (2006). Digital orthophoto quadrangles (DOQs). http://eros.usgs.gov/products/aerial/doq.html.

Utton, A.E. (1999). Coping with drought on an international river under stress: The case of the Rio Grande/Rio Bravo. Nat. Resour. $J ., 39(1), 27-34$.

Vi Risser, M. (1995). The Rio Grande, the Desert's Lifeblood. The Big Bend Paisano, National Park Service, 17, 19.

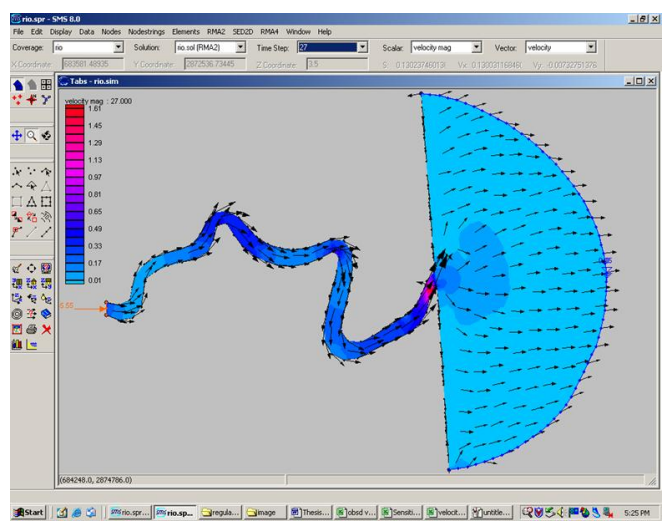

Figure A2. Snap shot of the water flow during the first low tide at 27 th hour. 


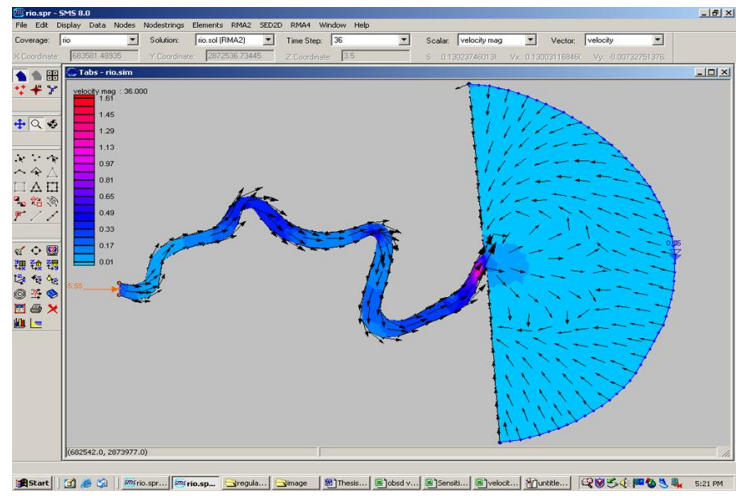

Figure A3. Snap shot of the water flow during the second high tide at 36 th hour.

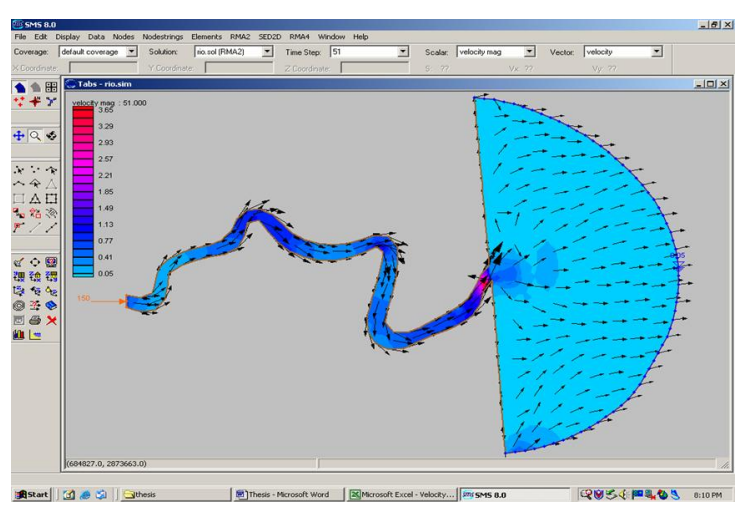

Figure A5. Snapshot of the water flowing and the velocity magnitude at an increased discharge of $150 \mathrm{cfs}$.

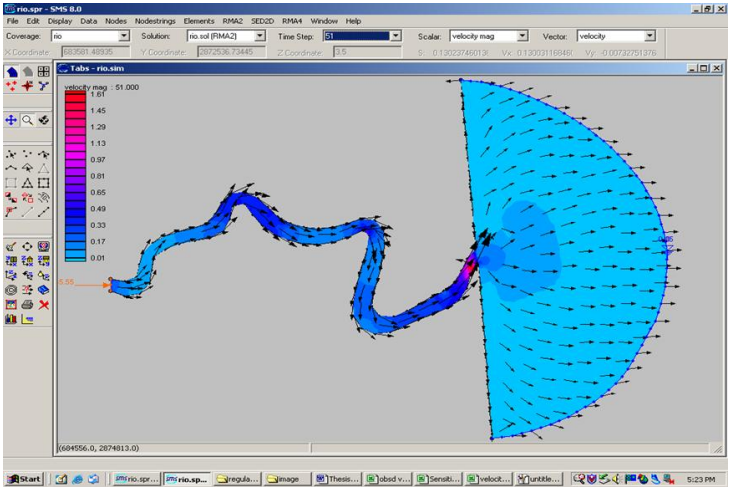

Figure A4. Snap shot of the water flow during the second low tide at 51 st hour.

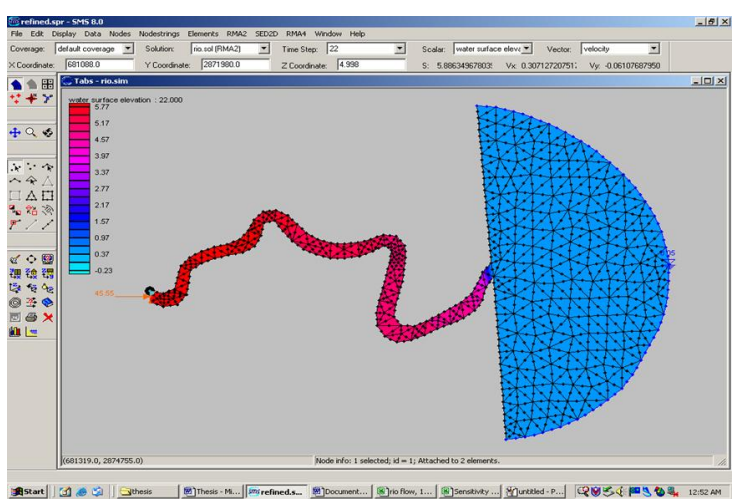

Figure A6. Water surface elevation at the inflow boundary condition.

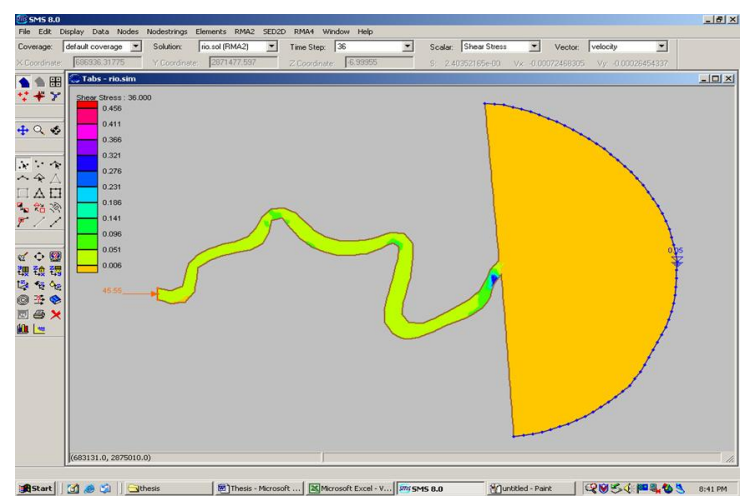

Figure A7. Snap shot of the Shear Stress calculated with the Data Calculator option. 